
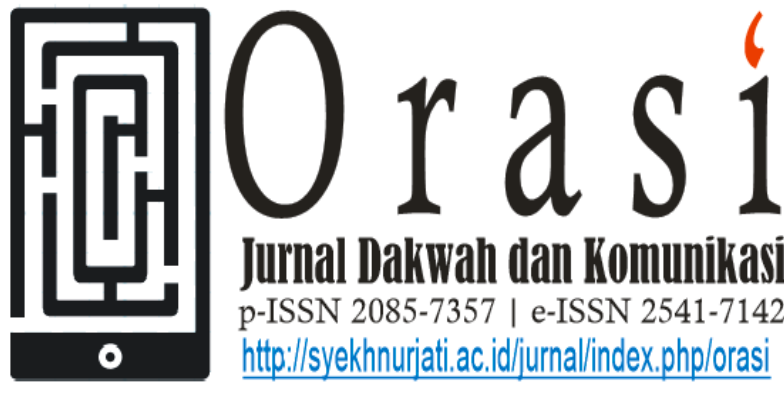

Volume 9 No. 1, PP 127 - 143; Juli 2018

\title{
STRATEGI DAKWAH BIL HAL DALAM PROGRAM POSDAYA BERBASIS MASJID
}

\author{
Zakiyyah 1(*), Arif Abdul Haqq2 \\ Dosen Jurusan Pendidikan IPA, Universitas Muhammadiyah Cirebon \\ Dosen Jurusan Tadris Matematika, IAIN Syekh Nurjati Cirebon \\ mrs.zakiyyahhaqq@gmail.com ${ }^{(*)}$,mr.haqq@gmail.com
}

\begin{abstract}
Penlitian ini bertujuan untukn memberi gambaran secara menyeluruh tentang implmenetasi strategi dakwah bil hal dalam program posdaya berbasis masjid. Mendeskripsikan permasalahan yang terjadi di masyarakat dan penanggulangannya melalui program lima pilar bidang POSDAYA. Jenis Penelitian adalah Kualitatif deskriptifdengan pengumpulan data melalaui wawancara, observasi dan dokumentasi, analisis penelitian menggunakan analisis deskriftif kualitatif. Hasil penelitian menunjukkan bahwa pelaksanaan Dakwah posdaya berbasis masjid dilaksanakan sejak tahun 2017 di Desa Sumurkondang Kecamatan Karangwareng Kabupaten Cirebon dengan mengoptimalkan perang masjid sebagai tempat sentra kegiatan, faktor pendukung dakwah posdaya berbasis masjid adalah asanya lingkaran-lingkaran kecil lima pilar yang bersinergi dalam mengelola masjid sebagai tempat segala kegiatan serta dukungan dari pemerintah, tokoh masyarakata, tokoh agama, dan tokoh pemuda termasuk majlis taklim. Adapun tantangan yang dihadapi adalah masih kurangnya sosialisasi dan pemahaman para pengurus masjid terhadap strategi Dakwah bil hal POSDAYA berbasis masjid. Untuk maksimalkan program Dakwah Posdaya berbasis masjid, maka dirumuskan berbagai kegaiatan yang mendukung program dakwah berbasis masjid seperti fungsi-fungsi dalam lima pilar, yaitu bidang pendididkan, bidang kesehatan, bidang ekonomi, bidang lingkungan dan bidang keagamaan.
\end{abstract}

Kata Kunci: Bil hal, dakwah, POSDAYA, masyarakat, kontekstual 


\section{PENDAHULUAN}

Strategi Dakwah bil hal adalah strategi mentransfer seruan nilai-nilai agama melalui tindakan suri tauladan yang nyata. Hal ini dimaksudkan agar si penerima dakwah (al-mad'ūlah) mengikuti jejak dan hal ikhwal si da'i (juru dakwah). Menurut Kurniawan (Bil Hal Penciptaan Budaya Agama melalui Pembiasaan Shalat Berjamaah di Sekolah Menengah Pertama Islam Al-Azhar 5 Kota Cirebon, 2017) dakwah bil hal (ajakan keagamaan dengan pemberian contoh perbuatan) perlu dilakukan tidak hanya sekedar transfer of knowledge tetapi juga untuk menanamkan nilai-nilai (transfer of values). Strategi dakwah jenis ini sangatlah efektif dan efisien bagi penerima dakwah. Al-Mawar (AlDakwah; Qawā’idwa Ushūl Mesir:, 1992, hal. 18) mengemukakan bahwa diakwah bi al-hāl, yaitu dakwah yang dilakukan dengan berbagai perbuatan dan kegiatan yang langsung menyentuh kepada masyarakat sebagai objek dakwah dengan karya.

Bentuk nyata kegiatan strategi dakwah bil hal senantiasa disertai dengan upaya-upaya ajakan nilai-nilai yang positif, terutama nilai-nilai religius. Kegiatan tersebut menurut Amin (Konsep Dakwah Melalui Program Posdaya Berbasis Masjid, 2012) di antaranya bersilaturrahmi dengan masyarakat yang membutuhkan, turut serta dalam melaksanakan pengabdian kepada masyarakat, ringkasnya adalah strategi dakwah ini dilaksanakan sesuai kebutuhan masyarakat dengan ramburambu dalam menjalani kehidupan. Konsepsi riil Islam tentang agenda dakwah sebenarnya telah ada dan masih banyak namun belum menjadi fokus untuk dikaji dan dikembangkan secara sistematis sehingga bisa dilakukan oleh banyak pihak (Hidayat, 2013). Lebih lanjut ia menuturkan optimalisasi dana wakaf, zakat, hibah yang dibuatkan sistem dan prinsip-prinsip kerja yang baik serta pengaturannya secara luas sehingga menjadi agenda bersama umat Islam untuk mengembangkannya.

Salah satu wujud nyata pengabdian kepada masyarakat adalah pelaksanaan program POSDAYA berbasis mesjid yang jelas merupakan bagian dari dakwah bil hal. Dalam praktiknya, mahasiswa diharapkan mampu mengaplikasikan ilmu pengetahuan yang bersifat teori ke dalam lingkungan nyata sehingga diharapkan adanya kerjasama antara perguruan tinggi dan masyarakat. Dalam rangka meningkatkan percepatan pembangunan serta mewujudkan sinergitas dan harmonisasi pembangunan melalui peningkatan peran lembaga pendidikan secara terintegrasi maka diselenggarakan pengabdian kepada masyarakat berupa POS 
Pemberdayaan Keluarga (POSDAYA). POSDAYA merupakan sebuah wadah atau lembaga yang berfungsi sebagai forum diskusi, silaturahmi, advokasi, komunikasi, edukasi, dan wadah kegiatan penguatan fungsi-fungsi keluarga secara terpadu yang dilaksanakan dari, oleh, dan untuk keluarga dan masyarakat.Salah satu POSDAYA yang dapat diberdayakan di masyarakat yaitu POSDAYA berbasis masjid.

Seiring dengan perkembangan zaman, bentuk dakwah yang berbasis Masjid diberi nama program dakwah pos pemberdayaan keluarga atau POSDAYA (Tike, 2018). Basis masjid dipilih karena masjid merupakan sarana pemberdayaan umat yang memiliki peranan strategis dalam upaya peningkatan kualitas masyarakat baik dalam aspek sosial, keagamaan, maupun pendidikan. Dalam hal ini, masjid dilihat tidak hanya sebagai tempat atau sarana bagi umat muslim untuk melaksanakan ibadah shalat, tetapi masjid juga berfungsi sebagai pusat pemberdayaan berbagai aspek kehidupan selain kegiatan keagamaan bagi masyarakat.

Dengan mengusung masjid sebagai basisnya, mahasiswa yang melaksakan program POSDAYA memiliki satu peran yang cukup strategis, yaitu menyatukan birokrasi dan masyarakat yang berarti menyelaraskan peran pemerintahan dalam hal administrasi dengan keadaan nyata warga yang bersangkutan. Pengabdian kepada masyarakat direalisasikan dalam berbagai bentuk kegiatan yang relevan dengan permasalahan yang ada di tempat mahasiswa tersebut berada. Melalui penyelenggaraan kegiatan-kegiatan tersebut diharapkan dapat memotivasi dan membangkitkan semangat untuk lebih aktif, kreatif dan dinamis serta mandiri sehingga upaya menciptakan kesejahteraan dan kelayakan hidup masyarakat terwujud. Anton (2015) mengatakan bahwa kegiatan sosial kemasyarakatan yang direncanakan dari masjid telah menyadarkan masyarakat bahwa agama yang dianutnya terdapat hikmah-hikmah (wisdom) ketuhanan dan kemanusiaan yang mirip, atau bahkan sama antara satu sama lain, maka kearifan terdalam pada masingmasing tidak hanya dapat memerkaya dan mempersubur satu sama lain, tetapi juga dapat dan akan terus memberi kehangatan makna bagi mereka dan bahkan bagi masa depan anak-anaknya.

Dalam upaya untuk mempengaruhi ataupun mengajak anggota masyarakat untuk menuju ke arah perubahan dibutuhkan upaya yang dilakukan secara berulang-ulang dan tentu saja ini akan membutuhkan waktu yang cukup lama (Sukmawati, 2013). Mahasiswa merupakan salah satu bagian dari kalangan elit di masyarakat yang terdidik dan terampil, serta sebagai agen perubahan pada masyarakat seharusnya mempunyai 
pemikiran yang lebih maju dan cerah untuk bisa menciptakan Sumber Daya Masyarakat (SDM) yang kreatif dan inovatif yang sebagai salah satu penunjang utama kemajuan suatu bangsa. Tumbuhnya sikap kreatif dan inovatif inilah masyarakat mampu mengembangkan segala sesuatu yang mereka miliki menjadi hal yang bernilai dan diperuntukkan demi kemakmuran hidup mereka.

Mahasiswa memiliki peranan penting di areal kampus maupun di lingkungan masyarakat sekitarnya untuk berperan aktif melaksanakan strategi dakwah bil hal. Mahasiswa diharapkan mampu menyumbangkan pengetahuannya kepada masyarakat di lingkungan sekitarnya. Sebab masyarakat itu sendiri telah berparadigma bahwa mahasiswa adalah row models masyarakat di masa depan yang memiliki nilai kependidikan yang lebih dan berpengetahuan luas. Sehingga apabila mahasiswa dan masyarakat bisa saling bertoleransi dan saling bekerja sama, maka akan terbentuk kehidupan masyarakat yang lebih terjamin mutu pengetahuannya dan dapat bersamasama tumbuh dan berkembang dalam harmoni.

Berdasar pada uraian latar belakang yang telah dikemukakan, maka sebagai masalah pokok dalam tulisan ini adalah bagaimana konsep dakwah melalui program POSDAYA berbasis masjid ditinjau dari segi metodologi dakwah bil hal, dan sebagai sub masalah yang akan dibahas adalah: bagaimana konsep dakwah bil hal dalam kaitannya dengan program Posdaya berbasis masjid, bagaimana implementasi dakwah melalui Program POSDAYA berbasis Masjid berdasarkan metode dakwah bil hal.

\section{METODE PENELITIAN}

Pendekatan yang digunakan dalam penelitian ini adalah pendekatan kualitatif deskriptif. Usaha untuk melakukan penelusuran, pemahaman, penjelasan gejala dan kaitan hubungan antara gejala yang diteliti dari komponen tertentu menjadi dasar digunakannya pendekatan tersebut. Model yang digunakan untuk melakukan analisis data adalah Model Analisis Interaktif Miles dan Huberman. Menurut Sukmawati (2013) model tersebut dapat memiliki empat tahapan, yaitu: (1) Tahap pengumpulan data, pada tahap ini peneliti melakukan proses pengumpulan data dengan menggunakan teknik pengumpulan data yang telah ditentukan; (2) Tahap reduksi data, pada tahap ini, peneliti melakukan pemilihan, pemusatan perhatian pada penyederhanaan, pengabstrakan, dan transformasi data kasar yang muncul dari catatan-catatan tertulis dari lapangan; (3) Tahap penyajian data, tahap ini merupakan penyajian data dari informasi yang tersusun yang memberi kemungkinan adanya penarikan 
kesimpulan dan pengambilan tindakan; dan yang terakhir adalah (4) Tahap verifikasi/penarikan kesimpulan, pada tahap ini merupakan tahap akhir, yang berupa penarikan kesimpulan dari data yang telah ditampilkan. Adapun ilustrasinya ditampilkan pada Gambar 1 berikut.

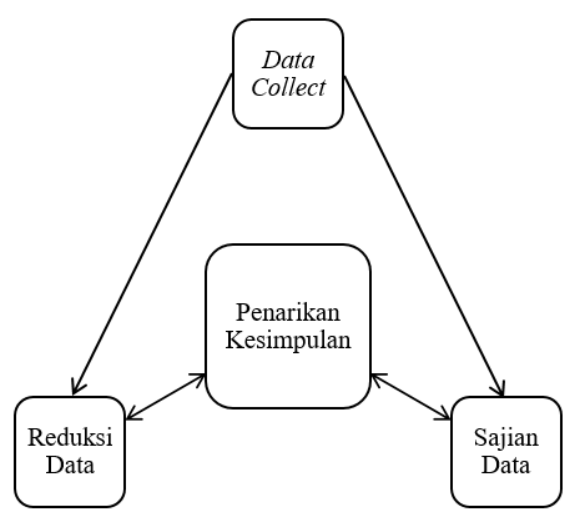

Gambar 1. Model Analisis Interaktif dari

Miles dan Huberman

Teknik pengumpulan data menggunakan metode: (1) pengamatan, yang digunakan untuk mengamati hasil berupa kondisi fisik apa saja yang telah dilaksanakan/diwujudkan oleh kepala desa dalam rangka pembaharuan kepada masyarakat tentang pertanian berbasis teknologi dan pendukungnya. Kegiatan masyarakat dalam mempraktekkan pertanian berbasis teknologi. Kegiatan lainnya yang mendukung pelaksanaan pembaharuan pada masyarakat Desa Mlatiharjo; (2) wawancara, yang dugnakan untuk mewawancarai kepala desa sebagai agen perubahan utama, perangkat desa, dan penduduk Desa Sumurkondang, dokumentasi, dokumen digunakan sebagai sumber sekunder, dalam hal ini berarti dokumen bias digunakan sebagai suatu cara untuk melakukan pengecekan silang (cross check) terhadap informasi yang telah diperoleh dari sumber lain, missal dari hasil wawancara; (4) triangulasi, yaitu tehnik yang menggabungkan beberapa teknik pengumpulan data dan sumber data yang telah ada. Uji objektivitas data penelitian ini dilakukan dengan menggunakan teknik: (1) triangulasi sumber, yaitu dengan melakukan pengecekan data tentang kondisi masyarakat dari sumber lisan (informan) seperti kepala desa, perangkat desa dan sumber pendukung lainnya dengan sumber tertulis (misal data monografi desa); (2) review informan, yaitu dengan melakukan pengecekan hasil penelitian oleh para informan.

\section{HASIL DAN PEMBAHASAN}

Posdaya Berbasis Masjid merupakan salah satu jenis pengabdian kepada masyarakat bertujuan membentuk, membina, dan mengembangkan Posdaya sebagai terobosan baru dalam pemberdayaan masyarakat, melalui pemanfaatan potensi SDM dan SDA lokal. Adapun tujuan kegiatan yang dilaksanakan adalah sebagai berikut:

1. Meningkatkan kepedulian dan kemampuan mahasiswa mempelajari dan mengatasi permasalahan keluarga dan penduduk melalui bantuan 
penyusunan rencana dan pendampingan pada pelaksanaan program yang inovatif dan kreatif melalui penerapan ilmu dan teknologi bersama masyarakat dan lembaga pedesaan lainya.

2. Meningkatkan kemampuan mahasiswa melaksanakan kegiatan pengembangan masyarakat sesuai arahan pembangunan manusia (human development), mencapai target dan sasaran Millennium Development Goals (MDGs), kompetensi, potensi, sumberdaya dan kemampuan lingkungan dalam wadah kerjasama masyarakat, pemerintah, swasta dan lembaga lainnya.

3. Menggalang komitmen, kepedulian dan kerjasama berbagai stakeholders (Pemda, swasta, LSM dan masyarakat) dalam mengatasi permasalahan dan ketidakberdayaan penduduk dan keluarga lainnya untuk mewujudkan keluarga sejahtera mandiri.

4. Membantu dalam mempersiapkan keluarga dan masyarakat agar memiliki kemampuan untuk memanfaatkan setiap fasilitas dan dukungan yang diberikan oleh mitra kerja pembangunan (pemerintah daerah, lembaga swasta dan LSM) dalam perencanaan dan pengelolaan program bersifat partisipatif.

5. Meningkatkan kemampuan dan kompetensi mahasiswa sesuai dengan bidang studi yang ditekuni.
6. Membantu kontribusi teoritis dan praktis dalam pengembangan kurikulum yang disesuaikan dengan kebutuhan pembangunan.

Keenam tujuan tersebut bisa dilakukan melalui pemberdayaan masjid dengan cara menggalakkan kegiatan dakwah, karena masjid sebagai pusat kehidupan agama, keluarga dan masyarakat bertujuan agar ekslusifitas masjid dirancang sebaik mungkin untuk memakmurkannya sebagaimana yang dipahami dalam Q.S. al-Taubah/9:18 yang terjemahnya: "Hanya yang memakmurkan masjid-masjid Allah ialah orang-orang yang beriman kepada Allah dan Hari kemudian, serta tetap mendirikan shalat, menunaikan zakat dan tidak takut (kepada siapapun) selain kepada Allah, maka merekalah orang-orang yang diharapkan termasuk golongan orangorang yang mendapat petunjuk”.

Dengan mengusung masjid sebagai basisnya, Desa Sumurkondang memiliki satu masjid yang cukup strategis, yaitu Masjid Baiturrahman. Masjid tersebut termasuk dalam lingkup Balai Desa Sumurkondang yang berperan sebagai pusat pemerintahan. Selain itu, masjid ini $\begin{array}{llll}\text { terletak di dekat SDN } 01 & \end{array}$ Sumurkondangyang merupakan lembaga pendidikan formal. Desa Sumurkondang juga memiliki 3mushola, yaitu mushola AlFallah, mushola Al-Hidayah dan mushola 
Nur-Shobah yang tersebar di seluruh wilayah desa.

\section{Meskipun Masjid Baiturrahman} tergolong kecil untuk ukuran masjid pada umumnya, masjid tersebut cukup ramai untuk dipakai berbagai kegiatan selain untuk shalat berjamaah, tarawih, dan shalat jumat. Kegiatan tersebut diantaranya yaitu sebagai tempat pengajian rutin ibu-ibu warga Desa Sumurkondang. Selain itu, keberadaan 3 mushola di Desa Sumurkondang lebih dari cukup untuk digunakan sebagai media silaturahmi dan sosialisasi kepada warga.

Secara administratif Desa Sumurkondang merupakan salah satu dari 9 Desa di wilayah Kecamatan Karangwareng, Kabupaten Cirebon yang terletak kurang lebih $7 \mathrm{~km}$ arah utara dari kota Sumber ibukota Kabupaten Cirebon berada di ketinggian 25 mdl diatas permukaan laut dengan wilayah kurang lebih $103.7031 \mathrm{Ha}$ dan terbagi menjadi dua dusun (04 RW, 12 $\mathrm{RT})$.

Desa Sumurkondang, sebagaimana desa-desa lain di wilayah Indonesia, mempunyai iklim kemarau dan penghujan, hal tersebut mempunyai pengaruh langsung terhadap pola tanam yang ada di Desa Sumurkondang Kecamatan Karangwareng. Iklim suatu daerah sangat berpengaruh dalam kehidupan utamanya untuk pertumbuhan tanaman dan kelangsungan hidup binatang ternak. Selain itu, kondisi geografis Desa Sumurkondang umumnya merupakan potensi daerah pertanian dan peternakan.

\section{Identifikasi Potensi dan Permasalahan} Masyarakat

Setelah melakukan survei dan penelusuran wilayah, di Desa Sumurkondang terdapat potensi yang dapat dijadikan sebagai pembangunan desa serta masalah yang dihadapi Desa Sumurkondang saat ini. Adapun masalah dan potensi-potensi yang dimiliki Desa Sumurkondang antara lain adalah sebagai berikut:

\section{Potensi Masyarakat Desa}

Selayaknya pembangunan yang ideal Desa Sumurkondangmemiliki potensi yang cukup besar, baik dari sumber daya manusia maupun sumber daya alam. Hingga saat ini, potensi sumber daya belum benar-benar optimal diberdayakan. Guna mendukung tercapainya pembangunan di Desa Sumurkondang, dilakukan survei di lingkungan desa, untuk mengetahui potensi sumber daya alam yang dapat dimanfaatkan untuk pembangunan, di antaranya sebagai berikut :

a. Sumber Daya Alam

Desa Sumurkondang adalah desa yang memiliki sumber daya alam yang dapat digunakan untuk mendukung pembangunan, diantaranya adalah sebagai berikut:

1) Lahan Persawahan 
Sebagaimana desa pada umumnya,

Desa Sumurkondang memiliki lahan persawahan untuk digunakan sebagai mata pencaharian penduduk.Areal persawahan tersebut dikelola dan dimanfaatkan oleh masyarakat untuk menanam tanaman padi. Area persawahan yang luas ini sampai sekarang terus dimanfaatkan oleh petani di Desa Sumurkondang untuk meningkatkan kesejahteraan ekonominya.

2) Hutan Produksi

Desa Sumurkondang yang letaknya berbatasan dengan kuningan membuat Desa Sumurkondang memiliki tingkat pembangunan yang kurang signifikan sehingga Desa Sumurkondang masih memiliki hutan yang cukup luas,area kehutanan Desa Sumurkondang memiliki potensi yang cukup besar khususnya hutan produksiyang luasnya mencapai $121,70 \mathrm{Ha}$ yang sering dimanfaatkan masyarakat khususnya untuk menanam pohon jati yang memiliki nilai ekonomis yang tinggi.

3) Hutan Konservasi

Desa Sumurkondang selain memiliki lahan pesawahan dan hutan produksi yang cukup luas, juga memiliki hutan konservasi yang luasnya mencapai 115,92 Ha, Hutan Konvservasi sendiri memiliki banyak manfaat bagi masyarakat begitupun untuk ekosistem lingkungan disekitarnya. Hingga sekarang keberadaan hutan konservasi masih dijaga dan dipertahankan oleh warga desa Sumurkondang.

b. Sumber Daya Manusia

1) Potensi tenaga kerja

Sumber daya manusia yang ada diDesa Sumurkondang bisa dikatakan memadai. Hal ini karena banyaknya warga Desa Sumurkondang yang berada pada usia produktif. Inilah yang nantinya bisa menjadi aset Desa Sumurkondangsebagai modal dasar yang dapat dimanfaatkan untuk pembangunan desa secara menyeluruh. Dengan adanya semangat gotong royong dari warga masyarakat, Desa Sumurkondang selalu siap untuk berperan aktif dalam pembangunan.

2) Pemerintahan Desa

Sebagai desa yang memiliki tatanan pemerintahan dan aturan, desa Sumurkondang memiliki aparatur pemerintah yang berperan aktif dalam pembangunan desa baik dari segi infrastruktur maupun masyarakatnya. Pembangunan dalam segi infrasturuktur dapat dilihat dari pembaharuan pembangunan jalan yang ada di wilayah tersebut yang mana seluruh desa dapat terjangkau dengan adanya kegiatan pengaspalan jalan serta pembuatan jalan menuju wisata sumur kramat. Dibidang lingkungan hampir semua lahan pekarangan rumah di desa Sumurkondang ditanami pohon mangga yang berfungsi sebagai penghijauan juga dapat menjadi 
nilai ekonomi jika mangga sudah berbuah, dari segi masyarakat pemerintah desa bersedia membangun wifi demi memenuhi kebutuhan masyarakat guna informasi dan sarana pendidikan yang dapat meningkatkan wawasan masyarakat, bukan hanya itu saja pemerintah desa juga sangat terbuka kepada tamu atau orang luar yang berkepentingan, hal ini dapat dilihat dari antusias Kepala Desa dalam membantu pengurus POSDAYA dalam merealisasikan program-program yang telah disusun.

3) Tokoh Agama dan Tokoh Masyarakat

Tokoh agama dan tokoh masyarakat yang ada di Desa Sumurkondang sangat berperan penting dalam meningkatkan kualitas moral dan perilaku warga masyarakat dengan berlandaskan keimanan dan ketaqwaan pada Allah Swt. Salah satu langkah yang dilakukan oleh tokoh agama ini yakni melaksanakan kegiatan maghrib mengaji di setiap harinya, dan mengadakan majelis ta'lim yang beranggotakan ibu-ibu yang sering melakukan pengajian tiap minggunya. Hal ini memberi peluang besar dalam menghidupkan masjid yang ada di Desa Sumurondang juga membantu anakanak di desa tersebut dalam memahami agama.

\section{Permasalahan Masyarakat Desa}

Tentunya sebagai desa yang masih berada dalam tahap perkembangan dan pembangunan, Desa Sumurkondang memiliki beberapa masalah yang dihadapi oleh masyarakat untuk mewujudkan citacita luhur Desa Sumurkondang. Masalah yang dihadapi di Desa Sumurkondangmencakup beberapa aspek seperti halnya dalam pelaksanaan pembangunan, kondisi geografis, dan keadaan sarana prasarana yang belum seutuhnya dapat dimanfaatkan dengan maksimal. Di bidang infrastruktur juga desa ini memiliki permasalahan yang berakibat menghambat pembangunan yang ada. Adapun masalah infrastruktur yang kini dihadapi oleh Desa Sumurkondang antara lain sebagai berikut:

a. Gedung Pendidikan

Berdasarkan data jumlah penduduk yang diperoleh di dapat bahwa jumlah warga Desa Sumurkondangyang masih harus mengenyam pendidikan masih cukup banyak, maka Desa Sumurkondang idealnya harus memiliki gedung pendidikan untuk menunjang kegiatan belajar mengajar untuk para murid. Namun, pada kenyataannya gedung pendidikan seperti SDhanya ada satu di Desa Sumurkondang ditambah keadaan gedung tersebutyang dikategorikan rusak ringan memaksa beberapa anak harus sekolah di luar desa. Sedangkan untuk tingkat SMP dan SMA tidak dibangun yang berimbas pada kurangnya kesadaran program pendididikan 12 tahun sehingga banyak anak yang putus sekolahdan banyak anak 
yang mengalami kesulitan untuk pergi ke sekolah di luar desa karena kurangnya kendaraan umum bagi yang tidak memiliki kendaraan.

b. Gedung Kesehatan

Untuk menunjang kesehatan warga Desa Sumurkondang, hingga saat ini baru memiliki satu unit Puskesdes yang masih memiliki keterbatasan dan mempunyai duabangunan posyandu, namun hanya satu posyandu yang aktif melakukan kegiatan. Hal ini akhirnya meyebabkan permasalahan bagi warga yang ingin memperoleh pelayanan kesehatan dan fasilitas kesehatan dari ahli medis karena Puskesdes hanya ada setiap menggu tidak setiap hari.

c. Sampah

Permasalahan yang sering dan banyak dijumpai di setiap daerah salah satunya di Desa Sumurkondangyaitu masalah penanggulangan sampah, meskipun telah dibangun Tempat Pembuangan Akhir (TPA) masyarakat tetap saja membuang sampah ke sungai dan kebun sekitar jalan desa, sehingga menimbulkan bau dan pemandangan yang kurang baik.Kesadaran akan membuang sampah pada tempaatanya dan rasa peduli masih sangat kurang karena mesipun telah diberi sosiaisasi masyarakat masih melakukakan perbuatan tersebut.

\section{Implementasi Strategi Dakwah Bil Hal dala Program POSDAYA}

1. Pembentukan Kembali IRMAS a. Latar Belakang

IRMAS (Ikatan Remaja Masjid) adalah suatu organisasi yang mengumpulkan seluruh remaja dalam suatu ikatan atau perkumpulan dengan tujuan akhir untuk mensejahterakan masjid. IRMAS berperan sebagai pembentuk karakter remaja yang mencintai masjid karena dengan IRMAS diharapkan berbagai kegiatan keagamaan yang berbasis masjid dapat di rangkul dan dilaksanakan oleh para anggota IRMAS. Para remaja yang sedang menghadapi masa puber sangat rentan oleh hal-hal negatif karena pada masa tersebut dihadapkan kepada berbagai kondisi yang membuat remaja dapat terjerumus kepada hal yang tidak sepatutnya dilakukan oleh sebab itu dengan dibentuknya IRMAS diharapkan para remaja dalam mengahadapi masa puber dapat dibentengi dengan ke imanan dan ketakwaan sehingga membentuk karakter remaja yang berakhlak mulia.

b. Tujuan dan Manfaat

Tujuan dari IRMAS yaitu berperan dalam hal penyebaran agama islam. Sedangkan manfaat dari IRMAS yaitu mengarahkan generasi muda untuk mengenal jati diri mereka dan tidak terombang ambing dalam menentukan jalan hidup serta membantu memotivasi dan menggali potensi diri para remaja.

2. Program Bimbingan Belajar dan 
Pengembangan Budaya Mengaji Qur'an

(Maghrib Mengaji)

a. Latar Belakang

Al-qur'an adalah kitab suci umat Islam dan merupakan pedoman hidup bagi umat manusia, namun karena perkembangan zaman dan era globalisasi banyak umat islam sendiri yang meninggalkan Al-Qur'an dan hanya menganggap Al-Qur'an sebagai benda pajangan, oleh sebab itu demi mebentuk generasi muda yang cinta Al-Qur'an diadakan suatu kegiatan maghrib mengaji yang diharapkan membentuk generasi muda yang cinta Al-Qur'an dan dapat mengamalkannya.

b. Tujuan dan Manfaat

Tujuan diadakannya program Maghrib Mengaji yaitu untuk meningkatkan kemampuan anak-anak dan remaja Desa Sumurkondang dalam hal baca tulis Al-Qur'an,selain itu dalam kegiatan ini diajarkan pulapembelajaran akidah dan akhlak untuk anak-anak dengan tujuan untuk menanamkan perilaku dan budaya islami. Sedangkan manfaat dari program Maghrib mengaji adalah agar anak-anak lebih memahami dan mampumembaca AlQur'an disertai ilmu tajwidnya.

c. Waktu dan Tempat Pelaksanaan

Pelaksanan program Maghrib mengaji dilakukansetiap hari pukul 17.30 sampai 19.30 WIB di Musholla, Masjid dan majlis ta'lim Desa Sumurkondang.

\section{d. Hasil Kegiatan}

Dengan adanya maghrib mengaji ini menjadikan anak-anak dan remaja terdorong untuk lebih belajar Al-Qur'an dan mengaji ke musholla dengan di bimbing oleh ustadz dan ustadzah di masing-masing musholla serta mereka lebih memahami cara baca Al-qur'an dengan tajwid yang tartil dan lebih sopan dalam berperilku..

3. Program pendidikan 1921 (19.00-21.00) a. Latar Belakang

Pendidikan adalah hal yang wajib dimiliki oleh setiap manusia. Dengan adanya pendidikan, kehidupan manusia akan semakin berkembang dan dapat mempermudah segala pekerjaan. Pemerintah sendiri telah mengadakan berbagai program pendidikan untuk mencapai tujuan mencerdasan kehidupan bangsa yaitu seperti halnya program wajib belajar 12 tahun. Selain itu, baru-baru inipemerintah mengadakan program 1921. Program 19-21 yaitu suatu program yang bertujuan mengajak anak-anak lebih giat belajar pada waktu prime-timeagar dapat melupakan hal-hal yang kurang bermanfaat seperti bermain game online, gadget, WIFI, dan menonton televisi.

Program 1921 ini bertujuan agar dapat mengembangkan kemampuan anakanak dan remaja yang ada di Desa Sumurkondang. Terutama yaitu yang sudah diajarkan di sekolah masing-masing seperti 
kemampuan Bahasa yaitu Bahasa Arab dan

Bahasa Inggris, kemampuan Matematika, IPA, IPS, Seni Budaya, dan kemampuankemampuan lainnya. Selain itu, program ini juga dapat mengembangkan minat dan bakat anak-anak dan remaja yang ada di Desa Sumurkondang.

b. Tujuan dan Manfaat

Memberikan ilmu pendidikan mengenai Bahasa seperti Bahasa Inggris dan Bahasa Arab, Matematika, IPA, IPS, dan Seni Budaya. Dalam program ini diharapkan anak-anak dan remaja Desa Sumurkondang dapat memahami dan mengembangkan minat dan bakatnya.

c. Waktu dan Tempat Pelaksanaan

Dilaksanakan setiap hari, kecuali hari Kamis dan hari Sabtu pada pukul 19.00 - 21.00 WIB bertempat di Musholah yang ada di Desa Sumurkondang. Di Sumurkondang sendiri ada 1 Masjid dan 4 Mushola, yaitu Masjid Baiturrahman, Mushola Al falah, Mushola Nurushobah, Mushola Al hidayah, Mushola Hidayatullah.

d. Hasil Kegiatan

Dalam kegiatan pendidikan program 19.00-21.00 dengan memberikan semangat berupa dorongan atau motivasi kepada seluruh anak-anak di desa Sumurkondang ini, memberikan dampak efektif yaitu mereka semakin giat belajar, menambah ilmu pengetahuan baru (new of the knowladge) serta menambah wawasan berfikir sehingga memberikan mereka impuls supaya rajin belajar. Sebab, program pendidikan atau pembelajaran yang dilaksanakan telah disesuaikan dengan materi-materi pelajaran yang ada di sekolah di mana mereka belajar, maka program ini sangat bermanfaat untuk dijadikan sebagai program intensifitas belajar anak yang mana mereka selain belajar di sekolah juga mampu memperdalam ilmu pengetahuan yang sedang mereka pelajari. Hal itu, tentu tidak lepas dari minat dan bakat masng-masing, disertai metode belajar yang menyenangkan sehingga materi pelajaran apapun mudah dipahami oleh mereka peserta didik yang mengikuti program ini.

4. Pembentukan Majelis Dzikir dan Ta'lim

a. Latar Belakang

Majelis ta'lim adalah salah satu lembaga pendidikan diniyah non formal yang bertujuan meningkatkan keimanan dan ketakwaan kepada Allah SWT dan akhlak mulia bagi jamaahnya, serta mewujudkan rahmat bagi alam semesta. Karena berbagai manfaat dari majelis ta'lim serta untuk mempersatukan warga desa Sumurkondang maka pembentukan majelis dzikir dan ta'lim dianggap perlu terlebih lagi di dusun 1 belum ada kegiatan majelis dzikir dan ta'lim.

b. Tujuan dan Manfaat

Tujuan dari Majelis Ta'lim yaitu 
membina dan mengembangkan ajaran islam dalam rangka membentuk masyarakat yang bertaqwa kepada Allah SWT.Sebagai taman rekreasi rahaniyah, karena penyelenggaraannya yang santai.Ajang berlangsungnya silaturahmi misal yang dapat menghidup-suburkan dakwah dan ukhuwah islamiyah.Sebagai sarana dialog yang berkesinambungan antara para ulama dengan umat. Media penyampaian gagasan yang bermanfaat bagi pembangunan umat khususnya dan bangsa umumnya. Manfaat dari majelis Ta'lim yaitu sebagai tempat belajar, sebagai tempat kontak social dan mewujudkan minat sosial

5. Kegiatan Mengikuti Majlis Ta'lim

\section{a. Latar Belakang}

Majelis Ta'lim merupakan kegiatan yang hampir ada disetiap daerah, mulai dari kalangan ibu-ibu, bapak-bapak, bahkan ada juga kalangan remaja yang mengikuti kegiatan Majelis Ta'lim. Kegiatan ini bisa mempererat tali persaudaraan atau silaturahmi antara warga / jama'ah yang mengikuti kegiatan tersebut. Majelis Ta'lim dapat meningkatkan rasa keimanan dan katakwaan setiap pengikutnya. Kegiatan ini juga akan menumbuhkan sifat kebersamaan dan kesetaraan setiap orang.

b. Tujuan dan Manfaat

Tujuan dan manfaat dari majlis ta'lim sendiri yaitu untuk meningkatkan pengetahuan tentang ilmu agama khususnya Islam. Kegiatan ini juga dapat menjadi ladang persaudaraan dan silaturahmi.

c. Waktu dan Tempat Pelaksanaan

Kegiatan ini dilaksanakan pada hari jum'at pukul 07.00 hingga selesai di Masjid Baiturrahman, pada hari Sabtu pukul 07.00 hingga selesai di Musholla AlFallah, pada hari Sabtu pukul 17.00 hingga selesai di Musholla Nurusshobah, dan pada hari Senin pukul 07.00 hingga selesai di Majelis Ta'lim Hidayatullah.

6. ASIH (Ahad Bersih)

a. Latar Belakang

Suatu lingkungan yang asri, nyaman, dan bersih merupakan suatu keinginan bersama setiap orang. Bagaimana cara kita menjaga lingkungan agar sesuai dengan apa yang diinginkan adalah tanggung jawab dari setiap individu di lingkungan tersebut. Hal ini dikarenakan masalah kebersihan lingkungan setiap harinya menjadi suatu masalah yang berkembang dan kian menjadi perdebatan.

Problem lingkungan yang tidak kondusif seperti halnya kurangnya tempat pembuangan sampah menyebabkan tumpukan-tumpukan sampah di setiap sudut lingkungan menyebabkan lingkungan menjadi kotor dan tidak lagi nyaman untuk dilihat bahkan dihuni. Masalah tempat pembuangan akhir yang kurang layak dan memadai jugaakan menyebabkan permasalahan lain timbul seperti halnya 
polusi udara dan penyakit lainnya.Oleh karenanya, masyarakat yang sadar akan kebersihan diharapkan akan membuat perubahan terutama pada lingkungan sekitarnya.

b. Tujuan dan Manfaat

Tujuan dari diadakannya ASIH yaitu membangun kesadaran masyarakat akan pentingnya kebersihan lingkungan. Dengan adanya program ini, diharapkan agar masyarakat tetap menjaga kebersihan lingkungan setiap harinya terutama di lingkungan sekitar rumahnya.

Manfaat dari ASIH yaitu menciptakan lingkungan yang nyaman dan bersihjuga bebas dari masalah-masalah kebersihan. Program ini juga diharapkan dapat membangun kebersamaan dan gotong royong antar warga masyarakat terutama dalam menangani masalah lingkungan.

\section{c. Hasil Kegiatan}

Kegiatan Asih ini mendapat respon yang baik dari masyarakat. Namun, hanya anak-anak yang ikut serta dalam pelaksanaannya. Sedangkan para warga masyarakat sendiri tidak ikut serta dan lebih memilih berdiam dimasing-masing rumah mereka. Namun dengan adanya respon antusiasme anak-anak menjadikan sebagian dari desa Sumurkondang menjadi rapih dan bersih.

7. Kebun Bergizi

a. Latar Belakang
Kebun gizi merupakan suatu tempat yang berisikan berbagai tanaman sayuran dan apotek hidup atau dewasa ini lebih dikenal sebagai tanaman herbaljuga ditanam di dalamnya yang nantinya dimanfaatkan untuk keperluan sehari-hari dan pengobatan. Sayuran yang akan ditanam di kebun gizi meliputi kacang panjang, buncis, lombok, dan lain sebagainya. Kebun gizi ini memiliki banyak manfaat karena tanaman-tanaman dan sayuran yang tersedia dapat langsung dibuat menjadi suplai vitamin dan aneka makanan pemenuh gizi warga serta tanaman herbalnya bisa dibuat obat dengan cara yang mudah.

Konsep kebun gizi kami adalah kebun yang dapat dimanfaatkan oleh seluruh warga. Artinya tanaman - tanaman yang dihasilkan di kebun gizi dapat diambil tanpa harus membayar. Hasil dari kebun gizi tersebut juga dapat dijual sehingga secara tidak langsung menambah pendapatan bagi keluarga yang ada di Kelurahan Sumurkondang.

b. Tujuan dan Manfaat

Tujuan dari adanya Kebun Bergizi yaitu memberikan wawasan kepada masyarakat tentang Hidroponik dan keuntungannya. Manfaat dari kebun bergizi, yaitu masyarakat mampu mengaplikasikan penanaman Hidroponik ditiap masing-masing pekarangan rumahnya. 


\section{c. Hasil Kegiatan}

Ketika kegiatan kebun bergizi ini dilaksanakan banyak masyarakat sekitar yang antusias untuk mengikuti menanam atau membuat kebun bergizi di halaman rumah mereka, selain itu juga masyarakat merasa kegiatan ini merupakan hal baru dan unik karena sebagian besar masyarakat banyak yang belum mengetahui masalah hydroponik.

8. Penyuluhan Kesehatan Masyarakat

a. Latar Belakang

Kesehatan adalah keadaan sejahtera dari badan, jiwa, dan sosial yang memungkinkan setiap orang hidup produktif secara sosial, dan ekonomis. Pemeliharaan kesehatan adalah upaya penaggulangan, dan pencegahan gangguankesehatan yang memerlukan pemeriksaan, pengobatan dan/atau perawatan termasuk kehamilan, dan persalinan.

Pelayanan kesehatan dapat juga dikatakan sebagai upaya pelayanan kesehatan yang melembaga berdasarkan fungsi sosial di bidang pelayanan kesehatan bagi individu dan keluarga. Fungsi sosial disini berarti lebih mengutamakan pada unsur kemanusiaan dan tidak mengambil keuntungan secara komersial.

Pelayanan kesehatan masyarakat umumnya diselenggarakan secara bersamasama dalam suatu organisasi bahkan harus mengikutsertakan potensi masyarakat dengan sasaran utamanya adalah masyarakat secara keseluruhan. Upaya kesehatan yang ditujukan lebih pada penekanan upaya-upaya promosi (promotif) dan pencegahan (preventif). Upaya-upaya kesehatan tersebut harus bersifat menyeluruh, terpadu, berkelanjutan, berjenjang, profesional dan bermutu serta tidak bertentangan dengan kaidah ilmiah, norma sosial budaya, moral dan etika profesi

b. Tujuan dan Manfaat

1) Tujuan

Adapun tujuan yang ingin dicapai dari disivi kesehatan adalah untuk: mengetahui kesehatan yang dialami oleh masyarakat desa Sumurkondang, mengetahui perkembangan tumbuh dan kembang anak balita di desa Sumurkondang, agar ibu-ibu hamil mendapat pengetahuan seputar kehamilan dan persiapan yang harus dilakukan selama hamil, adapun hal-hal yang boleh dan tidak boleh yang dilakukan ibu hamil, agar ibuibu yang mempunyai balita mendapat pengetahuan seputar pemberian gizi yang seimbang untuk balita, agar anak-anak mengenal kesehatan sejak sedini mungkin

2) Manfaat

Manfaat kegiatan kesehatan ini agar masyarakat desa Sumurkondang mengenal tentang kesehatan sedini mungkin, dapat mempraktekannya dalam kehidupan sehari- 
hari dan mengamalkan ilmu yang sudah di dapat.

\section{c. Hasil Kegiatan}

Hasil kegiatan untuk program kesehatan itu sendiri yaitu untuk puskesdes. Adanyan puskesdes untuk membantu masyarakat dalam pengobatan. Keluhan sebagian besar masyarakat desa Sumurkondang adalah batuk dan pilek. Untuk obat-obatan dikirim dari puskesmas.Posyandu untuk mengetahui perkembangan balita yang ada di desa Sumurkondang dengan dibantu oleh ibu PKK. Jadi tumbuh kembang balita dan bayi dapat dipantau dengan baik. Untuk dokter kecil hasil kegitannya yaitu anak-anak dapat mengenal tentang kesehatan sejak sedini mungkin melalui kesehatan pribadi dan kegiatan yang sering dilakukan seperti mencuci tangan dengan baik dan benar dan menggosok gigi dan cara merawat gigi.

9. Kunjungan ke Home Industry pembutan tempe

a. Latar Belakang

Home industri atau industri rumah tangga merupakan salah satu penggerak perekonomian, khususnya di wilayah desa yang kegiatan produksi atau kegiatan usahanya dilakukan di sekitar rumah. Home industri dalam melakukan kegiatannya tidak berskala besar seperti halnya industri-industri pada umumnya yang kegitannya sudah di lakukan di sebuah pabrik, namun pada hakikatnya home industri juga ikut andil terhadap roda perekonmian karena dapat menjadi untuk menjadi sebuah usaha dengan skala besar.

b. Tujuan dan Manfaat

Tujuan dari kegiatan ini yaituuntuk menambah wawasan tentang proses pembuatan tempe dan pemasarannya, sedangkan manfaat dari kegiatan ini adalah kitadapat mengetahui cara pembuatan tempe mulai dari proses pembuatan tempe, pemasaran tempenya, dan pendapatan dari usaha tersebut baik perhari, perbulan dan perkebun.

c. Hasil Kegiatan

Hasil dari kegiataan ini didapat bahwa pemilik tempe hanya menfokuskan pada pengolahan pembuatan tempe saja, yang mana pemilik tempe tidak berkeinginan untuk mengembangkan usahanya seperti memperbesar jumlah produksi dan membuat variasi produk seperti kripik tempe atau olahan lain.

\section{KESIMPULAN}

Berdasar pada uraian yang telah dikemukakan di atas, maka penelitian ini dapat disimpulkan sebagai berikut: Strategi dakwah bil hal dalam program Pos Pemberdayaan Keluarga atau Posdaya dapat berupa forum kumunikasi, advokasi dan wadah kegiatan penguatan fungsifungsi keluarga secara terpadu, juga menjadi wadah pelayanan keluarga secara 
terpadu, yaitu pelayanan pengembangan keluarga secara berkelanjutan, dalam berbagai bidang, utamanya kesehatan, pendidikan dan wirausaha.

Strategi dakwah bil hal yang diterapkan mencakup aktivitas dalam lima pilar yaitu: bidang pendididkan, bidang kesehatan, bidang ekonomi, bidang lingkungan dan bidang keagamaan. Aktivitas- aktivitas tersebut memiliki multifungsi dan sarana mengembangkan potensi masyarakat tidak hanya lingkup ibadah dalam arti sempit tetapi juga aktivitas ibadah dalam arti luas untuk peningkatan kesejahteraan keluarga dan masyarakat.

Secara realitas masjid-masjid selama ini memang kebanyakan hanya difungsikan sebagai tempat ibadah secara ritual, maka dengan terimplementasinya kegiatan dakwah bi hal melalui program Posdaya berbasis masjid, ke depan masjid dapat menjadi sentra kegiatan kemasyarakatan mulai kegiatan ibadah, kegiatan pendidikan, kegiatan wanita, kegiatan koperasi, kegiatan kesehatan, bahkan kegiatan jurnalistik sebagai media dahwah sangat efektif dalam menjawab semua permasalahan yang terdapat di tengah-tengah masyarakat.

\section{DAFTAR PUSTAKA}

al-Mawardi. (1992). Al-Dakwah;

Qawā'idwa Ushūl Mesir: . Mesir: Dār alFikr.

Amin, M. (2012). Konsep Dakwah Melalui Program Posdaya Berbasis Masjid. Tabligh, 13(1), 97-108.

Hidayat, A. S. (2013). Membangun Dimensi Baru Dakwah Islam: Dari Dakwah Tekstual menuju Dakwah Kontekstual. Jurnal RISALAH, 24(2).

Kurniawan, A. (2017). Bil Hal Penciptaan Budaya Agama melalui Pembiasaan Shalat Berjamaah di Sekolah Menengah Pertama Islam Al-Azhar 5 Kota Cirebon. Orasi: Jurnal Dakwah dan Komunikasi, 8(1), 5067.

Rekonstruksi Spirit Harmoni melalui Kegiatan PKM Posdaya Berbasis Masjid di Kecamatan Pulung, Kabupaten Ponorogo. (2015). Mukhibat, 14(2), 55-67.

Sukmawati, A. W. (2013). Agen Perubahan dan Perannya terhadap Kondisi Sosial Masyarakat di Desa Milatiharjo Kecamatan Gajah Kabupaten Demak. Journal of Educational Social Studies, 2(1), 22-28.

Tike, A. (2018). Model Dakwah Berbasis Masjid. Jurnal Al-Khitabah,, 4(1), $17-31$. 